\title{
DETERMINANTS OF DOMESTIC
}

AND CROSS-BORDER BANK ACQUISITIONS IN THE EUROPEAN UNION

Ignacio Hernando, Maria s. Nieto and Larny D. Nall

Documentos de Trabajo N.0823

\section{BATCOUE ESPANA}


DETERMINANTS OF DOMESTIC AND CROSS-BORDER BANK ACQUISITIONS

IN THE EUROPEAN UNION 
DETERMINANTS OF DOMESTIC AND CROSS-BORDER BANK ACQUISITIONS IN THE EUROPEAN UNION ${ }^{(*)}$

Ignacio Hernando and María J. Nieto

BANCO DE ESPAÑA

Larry D. Wall

FEDERAL RESERVE BANK OF ATLANTA

(*) Ignacio Hernando (hernando@bde.es) and María J. Nieto (maria.nieto@bde.es) Banco de España. Address: Alcalá 48, 28014 Madrid (Spain), Larry D. Wall (larry.wall@atl.frb.org ): Federal Reserve Bank of Atlanta, 1000 Peachtree Street N. E. Atlanta, Georgia 30309-4470 (USA). The views expressed here are those of the authors and do not necessarily reflect those of the Banco de España, the Federal Reserve Bank of Atlanta or the Federal Reserve System.

The authors are grateful to the participants in the seminars organized by the Federal Reserve Bank of Atlanta (October 2007), Bank of Spain (April 2008), and University of North Dakota (September 2008) and the participants in the XV Foro de Finanzas (Palma de Mallorca, October 2007); Finlawmetrics Conference (Bocconi University, Milan, June 2008); INFINITY Conference on International Finance (Trinity College, Dublin, June 2008) and the European Financial Management Association Meeting (Athens, June 2008) as well as George Benston, Roberto Blanco, Ricardo Gimeno, Javier Suárez and an anonymous referee. Any errors are our own. 
The Working Paper Series seeks to disseminate original research in economics and finance. All papers have been anonymously refereed. By publishing these papers, the Banco de España aims to contribute to economic analysis and, in particular, to knowledge of the Spanish economy and its international environment.

The opinions and analyses in the Working Paper Series are the responsibility of the authors and, therefore, do not necessarily coincide with those of the Banco de España or the Eurosystem.

The Banco de España disseminates its main reports and most of its publications via the INTERNET at the following website: http://www.bde.es.

Reproduction for educational and non-commercial purposes is permitted provided that the source is acknowledged.

\section{(C) BANCO DE ESPAÑA, Madrid, 2008}

ISSN: 0213-2710 (print)

ISSN: 1579-8666 (on line)

Depósito legal:

Unidad de Publicaciones, Banco de España 


\begin{abstract}
This paper analyzes the determinants of bank acquisitions both within and across countries in the EU-25 over the period 1997-2004. The findings of this paper are broadly in line with those of the academic literature on the subject, which are mainly based on the US experience. Our results suggest poorly managed EU-25 banks (high cost to income) are more likely to be acquired by other EU-25 banks, in the same country. Nevertheless, this underperformance of target banks does hold for cross border bank acquisitions only if compared to the median of the market. Larger banks are more likely to be acquired by other banks in the same country. The probability of being acquired by another bank in the same market is larger for banks that are quoted in the stock market, which is consistent with the disciplinary character of listing in the stock markets. Finally, banks operating in more concentrated markets are less likely to be acquired by other banks operating within the same country but are more likely to be acquired by banks in other EU-25 countries.
\end{abstract}

Keywords: bank acquisitions, merger gains, probability of acquisition.

JEL Codes: G21, G34. 


\section{Introduction}

The development of a single financial market has been a long time objective for the European Union (EU). Its achievement received further impetus with the single market for financial services in the early 90's and later by the introduction of the Euro. Financial integration supports economic growth and, in the euro area, also contributes to collect the full benefits of monetary integration. Integration spurs financial development, and higher competition. The result is better and more complete financial intermediation at lower cost. Better financial intermediation, in turn, results in higher economic growth, and productivity increases. However, quantifying the benefits of financial integration is difficult and has a tendency to lead to underestimation, as indirect benefits and the dynamic interaction with other economic processes are hard to identify and model [Faruqee (2007)].

Pan-European banks could, in theory, have developed long ago, in practice cross-border banking remained rather limited until the launching of the Euro. Also, in theory, it is possible for large cross-border banks to expand their activities via the opening of de novo operations. However, practice around the world has shown that de novo operations are usually a costly and slow way for a bank to enter a new market. ${ }^{1}$ Thus, if a single financial market is to develop through cross-border banking, most likely it will require the acquisition of banks across Member boundaries within the EU.

While the EU has seen significant overall consolidation in its financial sector according to the European Commission (2005), the Economics and Finance Ministers of the EU expressed dissatisfaction with the extent of cross-border consolidation in $2004 .^{2}$ In response to a request from the Ministers, the European Commission (2005) studied the extent of cross-border takeovers and found that it was proceeding more slowly in the financial sector due to regulatory and economic barriers to takeovers.

According to market participants, an important regulatory barrier was political interference and misuse of supervisory powers. Perhaps partially due to these barriers, domestic deals have been, until recently, significantly larger than cross-border deals leading to "domestic champions" [European Commission (2005)]. EU policy makers have responded by issuing Directive 2007/44/CE of the European Parliament and the Council amending the procedural rules and evaluation criteria for prudential assessment of acquisitions and increase of shareholdings. The Directive defines shareholding thresholds that require notification to the host country supervisor (20; 30; 50\%), time for acknowledgement of receipt of notification by the host prudential supervisors (60 days), the length of the assessment period as well as the conditions for stopping the clock, the requirement of information to the acquirer and the criteria for stopping the cross-border acquisition.

Another important economic barrier according to the European Commission (2005) was the limited opportunities to pay for the deal by reducing costs. One important reason why costs were difficult to cut is that cross-border deals typically involved few duplicative

\footnotetext{
1. Dermine (2003) indicates that the number of foreign bank subsidiaries in Europe is high relative to the number of foreign branches. Both foreign subsidiaries and branches are more the result of takeovers than of greenfield investments. Also, Cabral et al. (2002) point out that the most effective way of gaining access to the retail banking sector is to merge with or acquire an existing local bank.

2. See the Annex to the European Commission (2005) for a summary of the results of the Minister's 13 September, 2004 discussion.
} 
operations. Cost cutting opportunities were also limited by governmental restrictions on laying off employees. In this regard, Carbó-Valverde et al. (2007) conclude that reliance on scale alone to raise cost efficiency to achieve intra- and inter-country dominance may not be sufficient in the EU banking market. The full benefits from greater scale are achieved in conjunction with labor market reforms allowing greater flexibility for banks to reduce their labor costs and control better their input mix.

The barriers to cross-border deals may not only reduce the frequency of cross-border takeovers but also change the types of banks that are acquired relative both to the type of banks acquired in domestic EU deals and relative to a market with fewer regulatory constraints such as the United States (US). For example, the cost inefficiency of potential takeover targets may be less important in cross-border deals in the EU than in domestic EU and US transactions.

The purpose of this paper is to identify the differences between the banks that were targets versus those that were not acquired in the first 25 members of the EU (the EU-25) over the period from 1997 through 2004. The results are compared with prior studies of takeovers in the US and the EU. The sample also includes both in-country and cross-border takeovers, allowing some comparison of the relative importance of improving operations and other considerations in domestic versus cross-border takeovers.

The rest of the paper is organized as follows. Section 2 presents the recent experience of domestic and cross border bank acquisitions in the EU. The economic rational of bank acquisitions both domestic and cross border as presented in the academic literature is analyzed in section 3. Section 4 describes the data as well as the univariate analysis while section 5 presents the results of the discrete choice models for our sample of European banks. Finally, section six concludes. 
In the $\mathrm{EU}$, the consolidation of the banking system is reflected in the overall increase of the size of the international banking groups and the importance of their cross border presence. Over the last decade, banks in the EU responded to the structural changes in the financial sector and increased competition by consolidating their activities in order to increase in size and scope. Against this background, the number of credit institutions in the EU-25 fell from 9,747 in 2001 to 8,684 in $2005 .^{3}$ This decrease was to a large extent explained by the M\&A within national boundaries. Allen et al. (2005) report 438 transactions that involved at least one credit institution of which $68 \%$ involved within border transactions over the period 2001-2004. ${ }^{4}$ This consolidation of the banking systems within countries in part reflects the efforts of at least some EU countries to create national champions that have the size to become major international players. The flip side of creating national champions firms is a downward trend in the number of credit institutions and a significantly increased the level of concentration in the local banking markets. The (asset weighted average) five firm concentration ratio across the EU-25 is $33 \%$ and this average increased to $45 \%$ in $2004 .^{5}$ This increase in concentration raises concerns anti-trust issues which eventually inhibit some with-in country combinations and encourage acquirers to look across borders. Domestic mergers may also create targets that have sufficiently large market share and perhaps also market power in their home market to be attractive to acquirers in other countries. ${ }^{6}$

The cross border bank consolidation that has occurred to date has not gotten to the point where it is likely to lead to real pan-European institutions in the short term. While the average acquiring banks are larger in cross-border deals than domestic deals according to the European Commission (2005), the average targets are the same size in domestic deals as in cross-border deals. The acquirer is more likely to take a minority ownership position in cross-border deals than in domestic deals. ${ }^{7}$ Moreover, until very recently cross-border banking consolidation has mainly taken place within regional areas in the EU. Indeed, two linkages can be clearly distinguished in the Benelux and the Nordic countries. In particular, in the latter case intra-regional deals represent $90 \%$ of the total value of the deals within EU15 involving at least one Nordic entity. This ratio is around $60 \%$ for the Benelux region.

Acquisitions in the new member states occurred perhaps because many Central and Eastern European countries suffered banking crises in the early years of their independence

3. See European Central Bank (2006). Credit institutions are banks, savings banks and savings and loan undertakings (cooperative banks). The number of credit institutions in each Member State includes the credit institutions under the law of that country, regardless of whether or not they are subsidiaries of foreign banks, and the branches of foreign banks in that Member State. If a foreign bank has several branches in a given country, then they are counted as a single branch. However, if the same bank has several subsidiaries, the latter are counted separately because they are considered to be separate legal entities.

4. See Díaz et al. (2004) for an analysis post-merger performance of European banks that looks at both the acquirers of banks and of other financial institutions.

5. See European Central Bank (2006). These figures for the EU-25 are computed as the weighted average of the C5 concentration ratios for each individual country, using total assets of each national banking system as weights. The set of five largest credit institutions in each country may vary over time.

6. Acquirers may prefer a large market share in each country in which they operate to spread the fixed costs of conforming to the local cultural, legal and regulatory environment. An acquirer seeking substantial market share in a target country may find it more efficient to acquire a single bank that is relatively large in its markets rather than purchase many smaller banks to obtain that market share.

7. Minority shareholdings are shareholding that are not controlling stakes and, by definition below $50 \%$. 
and allowed their failed banks to be acquired by foreign banks. ${ }^{8}$ Other special circumstances have fostered those acquisitions such as run-up to EU membership and the privatization process. Three new member states joined Luxembourg (the EU-15 country with the most cross-border banking) in having over $80 \%$ of their banking assets in banks from other EU countries, while three other new member countries have almost $60 \%$. Four of the new members also rank relatively highly with regard to the percentage of assets from third countries. ${ }^{9}$ Consequently, the accession of the new members has given added impetus to cross-border banking issues in the EU [García (2007)].

The literature on takeovers in the EU reflects the growing interest in financial consolidation in the EU. However, the literature on the EU remains small relative to the large number of studies of US bank takeovers. No study has yet examined the determinants of takeovers across the entire EU25, albeit a few studies discussed in the following section have examined the determinants of takeover targets in parts of the EU.

Some related studies have focused on the expected economic outcome of takeovers by analyzing the stock market returns of the participants around the time of the takeover announcement. Cybo-Ottone and Murgia (2000) study a sample of acquisitions announced in European markets where at least one of the parties was a bank from 1988 through 1997. As is often found in event studies of takeover announcements, the targets has significantly positive abnormal returns and the acquirer has insignificant abnormal returns, findings which held for both domestic and cross-border takeovers. However, the weighted average returns of the combined firms are significantly positive for domestic deals and insignificant for cross-border deals. In contrast, Beitel et al. (2004) look at acquisitions in the EU 15 where the acquiring organization was a bank over the sample period from 1985 to 2000. They find that the weighted average returns of the acquirer and target are not significantly influenced by whether the takeover is a cross-border acquisition in a multiple regression framework with controls for several possible determinants of the weighted average returns. ${ }^{10}$ Hagendorff, Collins, and Keasey (2008), also focus on banks from the EU 15 plus Switzerland over a more recent time period, from 1996-2004. They differ from the prior studies that focus on earlier time periods in that they find that acquirer returns are significantly positive for most of their event periods. Their results suggest that the more recent mergers may be qualitatively different from those in earlier periods suggesting that studies focusing on more recent mergers may provide more relevant to likely future takeovers.

8. See Lanine and Vander Vennet (2007) for a test of the efficiency versus market power hypotheses as explanations of bank takeovers in Central and Eastern Europe.

9. Data are lacking for a number of individual new member states because the ECB does not publish data when the number of subsidiaries or branches is less than three.

10. Similarly, Campa and Hernando (2006), analyzing a sample of financial firms in the European Union over the period 1998-2002, did not find significant differences in value creation between domestic and cross-border deals. 
Most of the literature on the characteristics of targets in bank takeovers focuses on U.S. banks, with a large fraction of the studies focusing on takeovers of publicly traded firms. The U.S. study most closely related to our paper is by Hannan and Pilloff (2007). They note that most U.S. studies either focus on narrow subsets of banks, such as publicly traded banks, or they have problems identifying changes in control. ${ }^{11}$ Hannan and Pilloff (2007) start with the universe of U.S. banks but avoid errors in identifying changes in control by using a commercial merger data set from SNL Financial which focuses exclusively on takeovers where there was a change in control. ${ }^{12}$ Hannan and Pilloff (2007) separate their sample into in-market and out-of-market acquisitions, a split that roughly corresponds to our split between domestic and cross-border deals.

A few recent papers also examine the determinants of takeovers in Europe. Molyneux (2003) highlights the desire to avoid regulatory, information and other barriers as the main motive for overseas expansion. Moreover, analyzing a sample of M\&As that took place in Europe between 1995 and 2000, he also finds that domestic deals are more motivated by cost efficiency considerations, whereas earnings diversification may be more important for cross-border bank deals. Lanine and Vander Vennet (2007) examine the determinants of Western European bank takeovers of targets in Central and Eastern Europe over the 1995 through 2002 period as a part of a broader study of the implications of bank takeovers in that area. Pasiouras, Tanna and Gaganis (2007) analyze takeover targets and acquirers in the EU-15 over the 1997 to 2002 period with a focus on the role of differences in regulation. ${ }^{13}$

This study is similar to Lanine and Vander Vennet (2007) and Pasiouras, Tanna and Gaganis (2007) in that it looks at traded and non-traded banks over more than one European country. However, this differs from both of the European bank takeover studies in two important ways. First, this paper analyzes both domestic and cross-border takeovers using the same model. Lanine and Vander Vennet (2007) focus exclusively in cross-border takeovers whereas Pasiouras, Tanna and Gaganis (2007) do not distinguish domestic from cross-border takeovers. Our analysis of both types of takeovers in the same model allows us to address the European Commission's dissatisfaction with the extent of cross-border consolidation. Second, the sample of banks better matches the responsibilities of the EU as this study is drawn from the entire EU-25 set of countries, whereas both prior studies used subsets of the EU-25.

This section surveys the literature on the determinants of bank takeovers, with special attention to the results in Hannan and Pilloff (2007), Lanine and Vander Vennet (2007),

\footnotetext{
11. The studies with very large samples, sometimes the universe of U.S. banks, often rely on the merger of bank charters to identify takeovers. Hannan and Pilloff (2007) note that this procedure produces errors in both directions because a large fraction of U.S. banks are owned by bank holding companies (BHCs). Bank mergers may occur without a change in control if a BHC merges two banks in which it previously had a controlling interest. Conversely, a change in control may occur without the target bank losing its charter if the target is acquired by a BHC that maintains the target's charter.

12. Hannan and Pilloff (2007) note that in the vast majority of their takeovers the acquirer's ownership interest goes from near zero (often exactly zero) to $100 \%$. As it is later explained, our use of a $20 \%$ threshold for change in control reflects a typical pattern of staggered shareholding acquisitions of banks in the EU. The participation of $20 \%$ is considered a permanent investment.

13. See also Buch and DeLong (2003), and Vander Vennet (2003) for related analysis.
} 
and Pasiouras, Tanna and Gaganis (2007). The section is organized around the various factors typically found to be the most likely determinants of bank acquisitions.

\subsection{Target operating performance}

One of the main motives underlying acquisitions is to improve the efficiency of the target. These gains are more likely to be achievable if the target bank is underperforming. Therefore, indicators of performance should contain explanatory power on the likelihood of being acquired. In particular, banks with lower profitability or inefficiency might be more attractive for acquisition. However, while it is true that underperforming banks provide greater opportunities for improvement, they are also more risky, especially if the source of the underperformance is a high level of bad loans. In such a case, a local acquirer may be in a better position to identify the problems that need to be fixed than an out-of-market acquirer. Thus, indicators of performance should a priori be more relevant to explain in-market acquisitions.

Hannan and Pilloff (2007) find that less profitable banks in the US are more likely to be acquired, regardless of the type of acquirer (except that the coefficient for large out-of-state acquirers is insignificantly negative), and a measure of inefficiency is found to be positively related to the probability of acquisition for the overall sample. ${ }^{14}$ The results from the two European studies differ. The coefficients on the expense ratios in equations predicting targets are insignificant in Lanine and Vander Vennet (2007). In contrast, the coefficient on the return on average equity is significantly negative and the one in the cost to income ratio significantly positive in Pasiouras, Tanna and Gaganis (2007).

\subsection{Capitalization}

An often researched determinant of the attractiveness of a bank as a potential target is its degree of capitalization. A number of different hypotheses for this relationship have been considered in the literature. On the one hand, there are some hypotheses that predict a positive relationship between banks' capitalization and the likelihood of being a target. First, if acquirers face regulatory pressure to increase capitalization they may seek highly capitalised targets. Second, if high capitalization indicates the inability of a bank to diversify assets, more capitalized banks would be more attractive for better diversified acquirers. Third, the managers of banks with high capital ratios may be operating further below their profit potential because of reduced pressure to obtain high earnings. On the other hand, some hypotheses predict a negative relationship. First, if capitalization is seen as an index of managerial ability or efficiency, then better capitalized banks would be less attractive to potential buyers, since the potential gains from a better management are smaller. Second, if a bank's capitalization is very low and the bank is near default, an acquisition by a well capitalized and efficient acquirer might be even fostered by the supervisor. Finally, another argument for a negative link suggested by Hannan and Pilloff (2007) is that buyers prefer high leveraged (poor capitalized) targets because it enables them to maximize the magnitude of post-merger performance gains relative to the cost of achieving those gains. For a given asset size, the purchase price premium of the acquisition is generally lower, the higher capitalized is the bank.

\footnotetext{
14. See Amel and Rhoades (1989) and Moore (1997) for additional references supporting the hypothesis that acquisitions serve to transfer assets from poorly managed to better managed firms. By contrast, Hannan and Rhoades (1987) and Hadlock et al. (1999) report evidence against the hypothesis of poor managerial performance as measured by ROA. Hadlock et al. (1999) argue that this evidence is most consistent with an entrenchment hypothesis, where management teams with significant ownership positions block attempts to be acquired at a reasonable price.
} 
Akhigbe et al. (2004) find a positive relationship between capital and the likelihood of being acquired in their sample of publicly traded banks in the U.S. However, most studies, including Hannan and Pilloff's (2007) results for their entire sample, and Lanine and Vander Vennet (2007) analysis of Central and Eastern European countries none of which were members of the EU before 2004, find that banks with higher capital-asset ratios are less likely to be acquired. The coefficient on the capital to asset ratio is insignificant in Pasiouras, Tanna and Gaganis (2007) using a sample of European countries that have been EU members since 1996 (EU-15).

\subsection{Prospects for future growth}

Banks experiencing high growth may be more attractive targets, as the potential gains arising from improved management after the acquisition are likely to be larger in banks that are operating in expanding markets. Consistent with this hypothesis, some U.S. studies from the 1980s, including Hannan and Rhoades (1987) and Cheng et al. (1989), find that the likelihood of acquisition is positively related to the growth rate of the assets of the target bank. However, Moore (1996) argues that slower growing targets may make more attractive to buyers looking to increase the target's growth rate. Consistent with Moore (1996), Pasiouras, Tanna and Gaganis (2007) obtain a negative coefficient on the past growth rate. Hannan and Pilloff (2007) and Lanine and Vander Vennet (2007) do not include a growth variable.

\subsection{Size}

Smaller banks may be more attractive to acquirers to the extent that these banks are more easily integrated into an acquirer's operations. Smaller banks are also less likely to raise concerns by the competition authorities. On the other hand, if the acquiring organization is seeking economies of scale or market power through the acquisition then acquiring one large bank may provide those economies or market power sooner and possibly at lower cost than a series of small acquisitions. Hannan and Pilloff (2007) find that larger banks are more likely to be acquired when they estimate their model using their full sample. Lanine and Vander Vennet (2007) and Pasiouras, Tanna and Gaganis (2007) also have a significantly positive coefficient on total assets. However, when Hannan and Pilloff (2007) focus on acquisitions by smaller acquirers they find that larger banks are less likely to be acquired, consistent with the hypothesis that post-merger integration becomes more difficult as the size of the target grows relative to that of the acquirer.

\subsection{Industry concentration}

The degree of concentration of the banking industry potentially affects the likelihood of acquisitions by conditioning the impact of the deals on the intensity of market competition and, consequently, affecting both the investment attractiveness of the target banks in that market and the likelihood of a sharp opposition by antitrust authorities. ${ }^{15}$ Therefore, the influence of concentration on acquisition likelihoods is likely to differ between domestic and cross-border deals since the reaction of competition authorities to domestic deals will likely to be more severe in more concentrated markets. However, in the case of cross-border deals that are less likely to be challenged by antitrust authorities, concentration may even positively affect the conditional probability of a cross-border acquisition if foreign acquirers are attracted by the higher margins that characterize more concentrated markets. Hannan and Pilloff (2007) fail to find any statistically significant evidence that competition issues are an important

15. Other studies such as Ashton and Khac (2008) empirically assess merger specific efficiency pass through into consumer prices as a standard for assessing the competitive effects of mergers. Specifically the relationship between efficiency gains achieved by merging firms and how these benefits are, or are not, passed on to their customers in the form of improved prices is examined. 
determinant of takeover targets. ${ }^{16}$ The coefficient on their measure of market concentration is consistently insignificant and the sign of the coefficient on their measure of size does not change between in-market and out-of-market acquisitions. However, Pasiouras, Tanna and Gaganis (2007) report a significantly negative coefficient on the five firm concentration ratio in their sample of European takeovers, perhaps reflecting differences in concentration with Hannan and Pilloff's U.S. sample.

\subsection{Management incentives}

To the extent that managers of the target banks may lose their job positions or, at least, may suffer a reduction in their executive autonomy or in their job responsibilities, they may oppose takeover bids even if the deals are value maximizing for their shareholders. In this line, Hadlock et al. (1999) explored the role of different variables that proxy target management incentives (such as ownership structure, board composition or characteristics of the top executive) in the likelihood of a bank to be acquired. The results in Hadlock et al. (1999) indicate that banks with higher levels of management ownership are less likely to be acquired, especially in acquisitions where target managers depart from the banking organization following the acquisition. Moreover, the authors do not find that poorly performing banks, as measured by ROA, are particularly likely to be acquired. Thus, they argue that this evidence is most consistent with the entrenchment hypothesis, where management teams with significant ownership positions block attempts to be acquired at a reasonable price, rather than with the discipline hypothesis.

In this paper, we do not explore the role of management incentives due to the lack of appropriate data. Nevertheless, these types of incentives are likely to have more explanatory power in studies on industries where hostile takeovers are more prevalent. However, as Cheng et al. (1989) indicate, this type of deal is rare in banking and difficult to implement due to regulatory hurdles. There are several recent examples in the European banking industry of hostile takeovers that did not succeed.

\subsection{Other target characteristics}

Lack of appropriate and good quality data also precludes us from considering in our empirical study other bank level potential determinants of bank acquisitions that have been studied in the U.S. literature. First, Wheelock and Wilson (2000) consider different indicators of asset quality and find that some proxies for suspect loans are negatively related to the probability of acquisition. We have not considered this type of ratio mainly because of the different regulatory criteria among countries and within countries over the study period. Second, Hannan and Pilloff (2007) study the role of the composition of the target's clientele and they find that the higher is the local nature of deposits the higher is the likelihood of being acquired [see also Ahkhigbe et al. (2004)]. They argue that this result may reflect the possibility of cross-selling new products to newly acquired local depositors. Finally, both Wheelock and Wilson (2000) and Hannan and Pilloff (2007) considers bank's age to capture the effect of length of time since opening in the probability of being acquired. They generally find a negative sign which they interpret as the age variable capturing an unobservable element of bank success.

16. Hannan and Rhoades (1987) and Moore (1997) find that the effect of concentration on the acquisitions likelihood is significantly positive for out-of-market acquisitions but negative for in-market acquisitions, thus reflecting the deterrence effect of antitrust enforcement. 


\section{$4 \quad$ Empirical approach}

\subsection{Statistical approach}

We first attempt to identify those observable characteristics that are related to a bank becoming a target. For this purpose, we estimate a logit model:

$$
P_{j t}=\frac{\exp \left(X_{j} \beta\right)}{\left(1+\exp \left(X_{j} \beta\right)\right)}
$$

where $P_{j t}$ is the probability of bank $\mathrm{j}$ being acquired in period $\mathrm{t}$; $X_{j}$ is a vector of explanatory characteristics (both bank-specific and market-specific) relevant to acquisitions in period $t$; and $\beta$ is a vector of coefficients.

As a second approach, we estimate a multinomial logit model that allows the effect of the explanatory variables to differ for acquisitions where both the target and the acquirer banks are located in the same country versus acquisitions where the target and acquired banks are located in different countries.

$$
P_{j t}^{D}=\frac{\exp \left(X_{j} \beta^{D}\right)}{\left(1+\exp \left(X_{j} \beta^{D}\right)+\exp \left(X_{j} \beta^{C B}\right)\right)}
$$

and

$$
P_{j t}^{C B}=\frac{\exp \left(X_{j} \beta^{C B}\right)}{\left(1+\exp \left(X_{j} \beta^{D}\right)+\exp \left(X_{j} \beta^{C B}\right)\right)}
$$

where $P^{D_{j t}}$ and $P^{C B_{j t}}$ denote the probability of being acquired in a domestic or cross-border transaction, respectively; and $\beta^{D}$ and $\beta^{C B}$ are vectors of coefficients. Thus, the influence of the explanatory characteristics (both bank-specific and market-specific) on the likelihood of being acquired is allowed to differ between acquisitions in the same or in a different country.

\subsection{Empirical model}

The empirical model is based on models that have been estimated using U.S. data with some modifications to reflect data availability and market differences in Europe. The model for estimating the probability of being acquired by another bank takes the form:

$P_{j t}=\alpha+\beta_{o p}\left(\right.$ OperatingPerformance $\left._{j t-1}\right)+\beta_{\text {cap }}\left(\right.$ Capitalization $\left._{j t-1}\right)+\beta_{g r}\left(\right.$ Growth $\left._{j t-1}\right)+$ $\beta_{m p}\left(\right.$ Size / MarketPower $\left.{ }_{j t-1}\right)+\beta_{o}\left(\right.$ Other $\left._{j t-1}\right)+\beta_{t}\left({\text { TimeFixedEffects })+\varepsilon_{j t}}\right.$ 
The multinomial models for $P^{D_{j t}}$ and $P^{C} B_{j t}$ are similar except for the appropriate change in the dependent variable. The independent financial and market specific variables are lagged one year.

Our empirical model has three proxies for the target's operating performance. The first is Bankscope's cost-to-income ratio, with higher values indicating greater cost inefficiency. ${ }^{17}$ Thus, the expected sign on the coefficient for this ratio is positive if worse performing banks provide greater opportunities to acquire. The other two proxies are the net interest margin which measures the interest spread between what the bank earns on its assets and pays on its liabilities (net interest income as a percentage of earning assets), and the return on average equity which measures of the overall returns to shareholders. The expected coefficients on these variables are negative if worse performing banks are more attractive targets but they may be positive if they are more resistant to being acquired.

The capitalization of the target is measured as the ratio of equity to total assets. As the studies of U.S. takeovers have found, the expected sign depends on which of several effects dominate. The relationship will be positive if: (1) acquirers face supervisory pressure to maintain or raise their post-acquisition capital ratios, (2) targets with higher capital ratios have less diversification or are operating less efficiently. The expected sign will be negative if: (1) higher target capital ratios are associated with more managerial ability; (2) banks that are near or below supervisory minimums are more likely to sell out, or (3) the acquirers will pay higher premiums as a proportion of equity for less well capitalized banks.

Growth opportunities are proxied with the annual growth rate of the target's assets and the annual growth rate of the target country's gross domestic product (GDP). The expected sign on both growth rates is positive if growing targets offer acquirer's the potential of larger gains from improved management. However, the sign may be negative if slower growing targets offer acquirer's better opportunities to improve management.

The proxy for a bank's size is its total assets at year end. The expected sign on this variable is positive if acquirers primarily value the fact that larger targets provide the acquirer with a larger position in the target's marketplace all else equal. However, the expected sign is negative to the extent that acquirer's primary concern is the difficulty in combining the target's operations with that of the acquirer.

The proxies for local market concentration are the five firm concentration ratio and the Hirschman-Herfindahl index $(\mathrm{HHI})$ where the market is defined as the country in which the bank is headquartered. ${ }^{18}$ All else equal, more concentrated markets may offer the acquirer higher profit opportunities. However, higher concentration levels may reduce the probability of being acquired by an in market bank to the extent that local bank supervisors seek to maintain competitive banking markets.

The Other variables proxy for the target's willingness to be acquired (including the type of business specialization ${ }^{19}$ : commercial banks, medium and long term banks and

17. Bankscope defines this as overhead expense as a percentage of the sum of net interest revenue and other operating income.

18. Member State's HHI is calculated according to a common methodology as established by the ECB [European Central Bank (2006)].

19. As an alternative to control for bank specialization, we have included in the regressions the ratio of other operating income over average assets in order to capture the importance of traditional lending versus fee-based activities. It could be argued that if banks with a high share of non-interest income are more likely to be acquired, earnings diversification is 
holding company banks) and for the unique conditions in the new members states of the EU. The proxy for the target's willingness is its stock listing, which takes a value of one if the bank is listed on the stock exchange and zero otherwise. The expected sign on this variable is positive as acquirers may have more ways of pressing reluctant target managers and boards to accept a takeover. That is potential acquirers of banks that are listed may threaten to acquire some of the target's stock and to appeal to the target's other shareholders for support of its takeover bid. The proxy for the new member states takes a value of one if the bank is headquartered in those countries that joined the EU after 2000 and before the last enlargement in 2007. The expected sign on this variable is positive. Acquisitions in the new member states often occurred because many Central and Eastern European countries suffered banking crises in the early years of their independence and allowed their failed banks to be acquired by foreign banks. Other special circumstances have fostered those acquisitions such as run-up to EU-25 membership and the privatization process.

a possible motivation for merger activity. However, this variable is consistently insignificant when included in the model presented below and the estimated values of the other coefficients and their statistical significance are essentially unchanged. 


\subsection{Sample selection}

The sample consists of banks from the EU-25 available on the Bankscope database from 1996 (before the introduction of the Euro) through 2004 (the last year prior the adoption of the international financial reporting standards _-IFRS - by the EU banks). ${ }^{20,21}$ Our database includes 5,493 observations corresponding to 1,342 EU-25 largely private banks incorporated as joint stock companies of which, 75 are independent institutions and the rest are subsidiaries of financial or non financial institutions as of last reporting year. All the sample banks have controlling European shareholding in order to exclude M\&As motivated by strategic decisions of non EU controlling shareholders. ${ }^{22}$

The data on acquisitions were obtained from the M\&As Deals Module of Thomson One Banker over the period starting in 1997 and ending just before the switch from national accounting standards to the IFRS in 2004. We have included only those transactions that involved a change in control where both the target and the acquirer were banking institutions. We have considered that a change in control takes place when a bank or bank holding company that owns less than $20 \%$ of the target's equity increases its shareholding to at least $20 \%$. This also represents a typical pattern of staggered shareholding acquisitions of banks in the EU [European Commission (2005)] and the minimum threshold for authorization by the prudential supervisors of the host country as established in the EU Directive. ${ }^{23}$ The sample of acquisitions in the EU-25 contains 157 deals, of which 39 were cross-border.

Table 1 provides information on the geographic distribution of the overall sample and thetakeover distribution (by host country of the target). Takeovers are split into domestic takeovers where the acquirer is from the same country and cross-border takeovers. Domestic takeovers are approximately three times as common during our sample period. Table 1 also provides a breakdown of the number of takeovers by year.

\subsection{Descriptive analysis of the sample of EU-25 banks}

Descriptive statistics and univariate analysis are broken down three ways and are provided in Tables 2, 3, and 4. Table 2 compares the performance of target and non-target banks for the entire sample. Table 3 compares the same performance measures for targets relative to the median values in the bank's market in which operates. Table 3 also compares the performance of listed and non-listed targets. Finally, Table 4 provides a univariate analysis of the differences between targets in domestic takeovers and the targets in cross-border takeovers. For the observations included in the target sample the variables are evaluated at

20. BankScope is a financial database covering 10,500 World Banks. It offers subscribers data up to 8 years of detailed spreadsheet information, compiled by FITCHIBCA mostly from the balance sheet, income statement and applicable notes found in audited annual reports. It also includes data details on ownership, produced by Bureau Van Dijk, such as lists of shareholders and lists of banking subsidiaries.

21. The characteristics of the sample banks are as follows for the EU25: Commercial banks; mortgage and real estate banks, medium and long term credit banks, bank holding companies, which all of them report on local GAAP. Banks with shareholders outside of the EU have been eliminated.

22. 21 are public or government controlled banks of which 9 are part of the Nordea Group. Only one of these banks belonging to the Nordea Group was a target bank in our sample. This deal cannot be considered a privatization.

23. In almost all cases, once an acquirer has more than $20 \%$ it ultimately buys at least $50 \%$ of the target during the study period. Also, it should be borne in mind that according to the IFRS adopted by the EU countries, the participation in the shareholding of $20 \%$ is considered as a permanent investment. 
the year immediately before the target bank is acquired. The variables are defined in the Appendix.

\subsubsection{TARGET VS NON- TARGET BANKS}

The results in Table 2 show that acquired bank in our sample are less profitable and have a higher ratio of cost to income at both the mean and median values. ${ }^{24}$ The median target bank had higher net interest revenue and other operating income as percentages of average assets but the differences are not significant at the mean values. The overall profitability results are consistent with the hypothesis that acquirers seek out poorly performing targets.

The scale of the target banks is generally similar to that of banks that were not acquired in Table 2, regardless of whether scale is measured by total assets, deposits and short-term funding, net income or employees. The only significant differences are in the median value of deposits and other short-term funding, and in the number of employees, where the target is significantly larger at the median but not at the mean.Finally, target banks are also not significantly different in their leverage ratio.

\subsubsection{TARGET BANKS VS NATIONAL MARKETS}

Table 3 shows means and medians of the financial ratios of the target banks relative to the median value of their respective market in which operates. The expense, revenue and profitability results in Table 3 for the sample as a whole are broadly consistent with those in Table 2. Targets have significantly higher cost to income ratios and other operating income to asset ratios (but not significantly different net interest revenue to average asset ratios). The net result is that targets have significantly lower profitability by all three measures (pre-tax operating income to assets, return on average assets and return on average equity). However, when the results are broken down by whether the target is listed on a stock exchange, the statistical significance appears to be entirely driven by banks that are not listed. ${ }^{25}$ This finding is consistent with Campa and Hernando (2006) who, analyzing a sample of acquisitions involving European listed banks over the period 1998-2002, show that although targets display on average a worse financial performance than their buyers, they do no significantly underperform with respect to the average bank of their national market.

Although the average target bank is similar in scale to the average bank in the EU in Table 2, Table 3 shows that target banks are typically larger along all four dimensions (total assets, deposits and short term funding, net income and total employees) than other banks in their country. The greater scale holds for all four of the scale variables, in terms of mean. The sole exception is that the mean scale in terms of net income of listed banks is not different from the mean scale of other banks in the target's home country.

Finally, results in terms of capitalization are not conclusive perhaps due to the small number of observations (see Table 3): the mean of the difference of the total capital ratio with respect to the country median is significantly positive while the median of this difference is significantly negative. This suggests that target banks tend to be less capitalized than their

24. The difference of means tests are generated from regressions that pool the data from the two groups of banks being compared. These regressions are specified as: $X_{i t}=a+b^{*} D_{i t}+e_{i t}$, where $X_{i t}$ is the variable being tested, $D_{i t}$ is a dummy equal to 1 for banks in the second of the two pooled samples, and $e_{i t}$ is a random disturbance term with zero mean. The statistical difference of $b$ from zero provides the test of statistical significance for the difference of means. In turn, the difference of median tests are nonparametric two-sample tests for the null hypothesis that the two samples of banks being compared were drawn from populations with the same median.

25. There are 221 listed banks and 1121 non-listed banks in our EU-25 sample. 
country median but there are a few non-listed target banks with very high capital ratios that seem to determine the positive sign of the mean.

\subsubsection{DOMESTIC VS CROSS-BORDER DEALS}

Table 4 shows the comparison between means and medians for both types of target banks and the statistical significance of the differences in their ratios. Differences between domestic and cross-border targets are in almost all cases not statistically significant. The only exceptions are the medians of the other operating income and pre-tax operating income over average asset ratios which are significantly higher in the case of cross-border targets. These results suggest that, a priori, both types of target banks tend to share similar financial characteristics. 


\section{$6 \quad$ Multivariate analysis: The probability of being acquired}

\subsection{Determinants of the likelihood of a bank being acquired}

The results of estimating the probability of being acquired in any takeover in the EU-25 presented in Table 5 are broadly consistent with the results found in Hannan and Pilloff (2007), and Pasiouras, Tanna and Gaganis (2007) with some exceptions. ${ }^{26}$ Consistent with their results, the coefficient on the cost to income ratio is positive and statistically significant. These results suggest that acquirers prefer to acquire banks with expense cutting opportunities. The coefficients on net interest revenue and return on average equity are insignificant.

The coefficient on the equity to asset ratio is close to zero and is statistically insignificant in Table 5. In contrast, Hannan and Pilloff (2007), and Pasiouras, Tanna and Gaganis (2007) both found a negative coefficient on this variable.

Probably the biggest inconsistency with the results typically obtained from U.S. data relate to growth. Hannan and Pilloff (2007) do not include a growth variable, but other studies that have done so tend to obtain a significantly positive coefficient. The annual total asset growth rate of the target's assets is insignificant in Table 5, but the GDP annual growth rate of the local economy is significantly negative. This result suggests that once we have controlled for bank-specific financial indicators, acquisitions are more likely in cyclical downturns. However, these results are broadly consistent with Pasiouras, Tanna and Gaganis's (2007) finding of a significantly negative coefficient on banks asset growth.

The results for size are consistent with Hannan and Pilloff (2007), Lanine and Vander Vennet (2007), and Pasiouras, Tanna and Gaganis (2007): Larger banks are more likely to be targets. We also use two proxies for market concentration, the five largest banks concentration ratio and the HHI. Differently from Pasiouras, Tanna and Gaganis (2007) but consistently with Hannan and Pilloff (2007), the market concentration variables are not statistically significant.

The coefficients on both whether the bank was listed and whether it was headquartered in a New Member State are significant. Banks that are listed in stock exchanges are more likely to be acquired, even after having controlled for size. Significantly positive coefficients are obtained for the dummy for New Member States reflecting the fact that bank acquisitions have been relatively frequent in these countries during the study period.

\footnotetext{
26. Risk considerations have been found to play an important role in bank mergers in Benston et al., 1995; and Buch and DeLong, 2008. We cannot replicate Buch and DeLong, 2008 stock market based measures of risk as our sample is dominated by non-listed firms, so we follow Benston et al., 1995 in using accounting measures to proxy for the variability of accounting earnings, specifically the standard deviation of ROA or standard deviation of ROE measured over the prior four years. In order to estimate these risk measures using data from prior periods, this part of our analysis focuses on the years 2000 to 2004 . We fail to find statistically significant differences between targets and non-acquired firms and between domestic and cross-border takeovers in the univariate analysis. Each of the risk measures was also included in separate estimations of our multivariate model. In all cases the risk of the target was statistically insignificant. As robustness checks, we also estimated the model with a variable that takes a value of 1 if the bank is independent, that is not owned by another firm (we use the Bankscope criteria for independence). This variable is not significant in any of the specifications and the results are qualitatively similar to those reported in the text.
} 


\subsection{Determinants of the likelihood of a bank being acquired by a domestic or foreign EU bank}

Table 6 displays the results of the estimation of a multinomial logit model that allows for different effects of the explanatory variables on the likelihood of being acquired by banks in the same country and on the likelihood of being acquired by banks in a different country within the EU25. ${ }^{27}$ Overall, the pattern of the results for the explanatory variables related to the conditional probability of domestic acquisitions is similar to those reported in the previous paragraphs. However, there is one important difference: the concentration variables are both negative and statistically significant indicating that acquisitions by banks operating in the same country are less likely in more concentrated markets.

Interestingly, the coefficients of the concentration variables are positive and statistically significant in explaining cross border acquisitions within the EU. Cross-border deals are less likely to increase concentration and, thus, raise competition concerns because a cross-border acquirer is likely to have little or no market share in the target's domestic market. Additionally, foreign banks may be attracted by the possibility of higher rents which might be obtained in more concentrated markets.

Figure 1 shows the marginal effects of an increase in bank cost efficiency and in market concentration on the probability of a bank being a target in a domestic and a cross border deal. While the probability of a bank being acquired in any given year is small, the coefficient estimates suggest that impact of some variables on the percentage change in the probability of being acquired can be substantial. For example, an increase in the five firm concentration ratio from $48 \%$ to $58 \%$ reduces (increases) the probability of a bank being target in a domestic (cross-border) deal from 1.6\% to $1.3 \%$ (from $0.4 \%$ to $0.5 \%$ ). These changes represent an approximate $20 \%$ decrease in the probability of a domestic acquisition and $20 \%$ increase in the probability of a cross-border deal. An increase in the cost to income from $64 \%$ to $74 \%$ has a smaller impact, increasing the probability of a bank being a target of a domestic deal from $1.8 \%$ to $1.9 \%$.

Most of the variables explaining the probability of a cross-border takeover are statistically insignificant, including the cost to income ratio. ${ }^{28}$ In addition to the significant positive coefficients on the concentration measures, the other significant coefficient is on stock exchange listing. This coefficient is positive suggesting that listed banks are more likely to be acquired, which may be explained by the greater information available on banks that are publicly traded.

The differences of the coefficients of the domestic and cross border regressions are only statistically significant in the case of the proxies for market concentration and the dummy for New Member States. ${ }^{29}$ One reason why precisely estimating the coefficients is difficult is the small number of cross-border transactions seems to explain the lack of significance of most coefficients in cross-border regression as well as most of the differences between coefficients in both regressions.

27. Multinomial Model: $1=$ Domestic target, $2=$ Cross border target, $0=$ Non target.

28. Nevertheless, the cost to income ratio is close to being significant. The $p$-values of its coefficient in columns 1 and 2 of Table 6 are 0.12 and 0.13 , respectively. As reported in Table 7, when the cost to income ratio is defined with respect to the median of the market it turns out to be significant.

29. The differences of the coefficients of the proxies for market concentration are significant at the $1 \%$ level. The difference of the coefficients of the New Member State is significant at the $10 \%$ level. 
Table 7 displays the estimation of multinomial logit models where the bank-specific financial ratios have been replaced for the corresponding ratios defined with respect to the median ratio of the banks operating in the same country. The main differences with Table 6 are that the coefficient on the cost to income ratio becomes significantly positive and the coefficient on stock market listing becomes statistically insignificant in the case of the cross-border deals. Banks which are being acquired cross-border are less efficient than other banks in their country but are no more likely to be listed on a stock exchange. ${ }^{30}$

30. Nevertheless, it has to be mentioned that the cost to income ratio was close to being significant in Table 6 ( $p$-values of 0.12 and 0.13 ) and that the stock listing dummy is close to being significant in the specifications reported in Table 7 (p-values of 0.15 and 0.12 ). 
There is considerable interest in bank consolidation within Europe, especially across member boundaries, but relatively little work has been done in this area. This paper adds to the growing literature on the determinants of which banks are acquired in two important ways. First, we analyze both within country and cross-border targets in the same model, allowing us to identify differences in the types of firms acquired in the two types of mergers. Second, we look at the entire EU-25 rather than a subset of EU countries. Our sample consists of 1342 private banks incorporated as joint stock companies under majority European shareholding. This sample contains both listed and non-listed banking firms, while most of the M\&A research focuses on listed banks. The sample includes 157 deals in which both the acquirer and the target where banks, of which 39 were cross-border. Our definition of change in control is consistent not only with the minimum threshold for authorization by the prudential supervisors of the host country established in the EU Directive but also with the typical pattern of staggered shareholding acquisitions of banks in the EU. The deals were announced between 1996 and 2004. The results on the determinants of cross-border transactions should be taken with some caution given the limited number of deals.

The findings of this paper are broadly in line with those of the academic literature on the subject including Hannan and Pilloff (2007), Lanine and Vander Vennet (2007), and Pasiouras, Tanna and Gaganis (2007). More precisely, the major conclusions of this paper are as follows:

- Although theory suggests that performance may be less important in determining European targets than U.S. targets, our results suggest poorly managed EU-25 banks (high cost to income) are more likely to be acquired by other EU-25 banks in the same country. This result supports the hypothesis that efficiency gains are more likely to be achievable if the target bank is underperforming. As a matter of fact, targets are less efficient than the median of its national market.

- Larger banks are more likely to be acquired by other banks in the same country. Moreover, targets are larger than the median of the market. This finding seems to reflect that the acquisition of large banks is more beneficial in terms of achieving product diversification and penetration in new market segments. This may also suggest that the supervisory authorities like to create national champions in the banking industry.

- Domestic acquisitions have been more likely in the New Member States reflecting the intense privatization process in these countries.

- Domestic and cross-border takeovers appear to differ in the area of market concentration. Domestic takeovers are less likely in more concentrated markets but cross-border takeovers are more likely. This seems to indicate that outside banks within the EU are attracted by high rents, which might be obtained in more concentrated markets, without these deals having an impact on market concentration and been challenged by the national authorities. 
- Also, our regression results suggest that inefficient and less profitable banks are not more likely to be targets in cross border deals. This finding is the most relevant difference with the empirical results obtained for the US banks. Hannan and Pilloff (2007) conclude that less profitable banks are more likely to be acquired, regardless the type of acquirer. Nonetheless, this result must be qualified since the coefficient of this ratio is statistically significant when compared to the median of the market. 


\section{REFERENCES}

AKHIGBE, A., J. MADURA and A. M. WHYTE (2004). "Partial anticipation and the gains to bank merger targets", Journal of Financial Services Research, 26 (1), pp. 55-71.

ALLEN, F., L. BARTILORO and O. KOWALEWSKI (2005). The financial system of the EU 25, mimeo.

AMEL, D. F., and S. A. RHOADES (1989). "Empirical evidence on the motives for bank mergers", Eastern Economic Journal, 15 (1), pp. 17-27.

ASHTON, J. K., and P. KHAC (2008). Efficiency and Price Effects of Horizontal Bank Mergers, mimeo.

BEITEL, P., D. SCHIERECK and M. WAHRENBURG (2004). "Explaining M\&A Success in European Banks", European Financial Management, 10 (1), pp. 109-139.

BENSTON, G. J., W. C. HUNTER and L. D. WALL (1995). "Motivations for Bank Mergers and Acquisitions: Enhancing the Deposit Insurance Put Option Versus Earnings Diversification", Journal of Money, Credit and Banking, 27 (3), pp. 777-788.

BUCH, C., and G. DELONG (2003). "Determinants of cross-border mergers in Europe: Is Europe different?", in Foreign direct investment in the real and financial sector of industrial countries, edited by Heinz Herrmann and Robert Lipsey, Springer (Heidelberg and New York), pp. 323-348.

- (2008). "Do Weak Supervisory Systems Encourage Bank Risk-Taking?", Journal of Financial Stability, 4 (1), pp. 23-39.

CABRAL, I., F. DIERICK and J. VESALA (2002). Banking Integration in the euro area, ECB Occasional Paper No. 6, December.

CAMPA. J. M., and I. HERNANDO (2006). "M\&As performance in the European financial industry", Journal of Banking and Finance, 30 (12), pp. 3367-3392.

CARBÓ-VALVERDE, S., D. HUMPHREY and R. LÓPEZ DEL PASO (2007). "Do cross-country differences in bank efficiency support a policy of "national champions?", Journal of Banking and Finance, 31 (7), pp. 2173-2188.

CHENG, D., B. GUP and L. WALL (1989). "Financial determinants of bank takeovers", Journal of Money, Credit, and Banking, 21 (4), pp. 524-536.

CYBO-OTTONE, A., and M. MURGIA (2000). "Mergers and shareholder wealth in European banking", Journal of Banking \& Finance, 24, pp. 831-859.

DERMINE, J. (2003). "European banking: past, present and future", in V. Gaspar, P. Hartmann and O. Sleijpen (eds.), The transformation of the European financial system, Proceedings of the 2nd ECB Central Banking Conference, ECB, Frankfurt, pp. 31-95

DÍAZ, B., M. GARCÍA OLALLA and S. SANFILIPPO AZOFRA (2004). "Bank acquisitions and performance: evidence from a panel of European credit entities”, Journal of Economics and Business, 56, pp. 377-404.

EUROPEAN CENTRAL BANK (2006). EU Banking Structures Report October 2006, European Central Bank.

EUROPEAN COMMISSION (2005). Cross-border consolidation in the EU financial sector, SEC (2005) 1398.

FARUQEE, H. (2007). "Financial Integration: Key Concepts, Benefits, and Risks", in Integrating Europe's Financial Markets, edited by Jörg Decressin, Hamid Faruqee and Wim Fonteyne, International Monetary Fund: Washington, DC.

GARCIA, G. G. H. (2007). Inter-state banking in the EU and the US: Similarities, differences and policy lessons, mimeo.

HADLOCK, C., J. HOUSTON and M. RYNGAERT (1999). "The role of managerial incentives in bank acquisitions", Journal of Banking and Finance, 23, pp. 221-249.

HAGENDORFF, J., M. COLLINS and K. KEASEY (2008). "Investor Protection and the Value Effects of Bank Merger Announcements in Europe and the US", Journal of Banking and Finance, 32 (7), pp. 1333-1348.

HANNAN, T., and S. PILLOFF (2007). Acquisition targets and motives in the banking industry, Board of Governors of the Federal Reserve System, unpublished Working Paper.

HANNAN, T., and S. A. RHOADES (1987). "Acquisition targets and motives: The case of the banking industry", The Review of Economics and Statistics, 69 (1), pp. 67-74.

LANINE, G., and R. VANDER VENNET (2007). "Microeconomic Determinants of Acquisitions of Eastern European Banks by Western European Banks", Economics of Transition, 15, (2), pp. 285-308.

MOLYNEUX, P. (2003). "Determinants of cross-border mergers in European banking", in Foreign direct investment in the real and financial sector of industrial countries, edited by Heinz Herrmann and Robert Lipsey, Springer (Heidelberg and New York), pp. 273-290.

MOORE, R. (1996). “Banking's Merger Fervor: Survival Of the Fittest?”, Financial Industry Studies, Federal Reserve Bank of Dallas, December, pp. 9-15.

MOORE, R. R. (1997). Bank acquisition determinants: implications for small business credit, Federal Reserve Bank of Dallas, Working Paper 9702

PASIOURAS, F., S. TANNA and C. GAGANIS (2007). What drives acquisitions in the EU banking industry? The role of bank regulation and supervision framework, bank specific and market specific factors, Coventry University, Economics, Finance and Accounting Applied Research Working Paper Series, No. 2007-3.

VANDER VENNET, R. (2003). "Cross-border mergers in European banking and bank efficiency", in Foreign direct investment in the real and financial sector of industrial countries, edited by Heinz Herrmann and Robert Lipsey, Springer (Heidelberg and New York), pp. 295-315.

WHEELOCK, D., and P. WILSON (2000). "Why do banks disappear? The determinants of U.S. bank failures and acquisitions", The Review of Economics and Statistics, 82 (1), pp. 127-138. 


\section{Annex: ${ }^{31}$}

\section{Capital adequacy ratio}

This ratio is the total capital adequacy ratio under the Basle rules. It measures Tier $1+$ Tier 2 capital which includes subordinated debt, hybrid capital, loan loss reserves and the valuation reserves as a percentage of risk weighted assets and off balance sheet risks. This ratio should be at least $8 \%$. This ratio cannot be calculated simply by looking at the balance sheet of a bank but has to be calculated internally by the bank. At their option they may publish this number in their annual report.

\section{Equity / tot assets}

As equity is a cushion against asset malfunction, this ratio measures the amount of protection afforded to the bank by the equity they invested in it. The higher this figure the more protection there is.

\section{Return on avg assets (ROAA)}

This is perhaps the most important single ratio in comparing the efficiency and operational performance of banks as it looks at the returns generated from the assets financed by the bank.

The mention "AVG" means that the item is averaged using the arithmetic mean of the value at the end of year $t$ and $t-1$. In order not to lose information, when figures are available for one year only, ratios implying average figures are nevertheless calculated using the values of the only available year.

\section{Return on avg equity (ROAE)}

The return on equity is a measure of the return on shareholder funds. Obviously here the higher the figure the better but one should be careful in putting too much weight on this ratio as it may be at the expense of an over leveraged balance sheet. The mention "AVG" means that the item is averaged using the arithmetic mean of the value at the end of year $t$ and $t-1$. In order not to lose information, when figures are available for one year only, ratios implying average figures are nevertheless calculated using the values of the only available year.

\section{Cost to income ratio}

This is one of the most focused on ratios currently and measures the overheads or costs of running the bank, the major element of which is normally salaries, as percentage of income generated before provisions. It is a measure of efficiency although if the lending margins in a particular country are very high then the ratio will improve as a result. It can be distorted by high net income from associates or volatile trading income.

31. Source: BankScope. 


\section{Net interest margin}

This ratio is the net interest income expressed as a percentage of earning assets. The higher this figure the cheaper the funding or the higher the margin the bank is commanding. Higher margins and profitability are desirable as long as the asset quality is being maintained.

\section{Net int inc / avg assets}

This ratio indicated the same but expressed as a percentage of the total balance sheet.

\section{Oth op inc / avg assets}

When compared to the above ratio, this indicates to what extent fees and other income represent a greater percentage of earnings of the bank. As long as this is not volatile trading income it can be seen as a lower risk form of income. The higher this figure is the better.

\section{Pre-tax op inc / avg assets}

This is a measure of the operating performance of the bank before tax and unusual items. This is a good measure of profitability unaffected by one off non trading activities. 

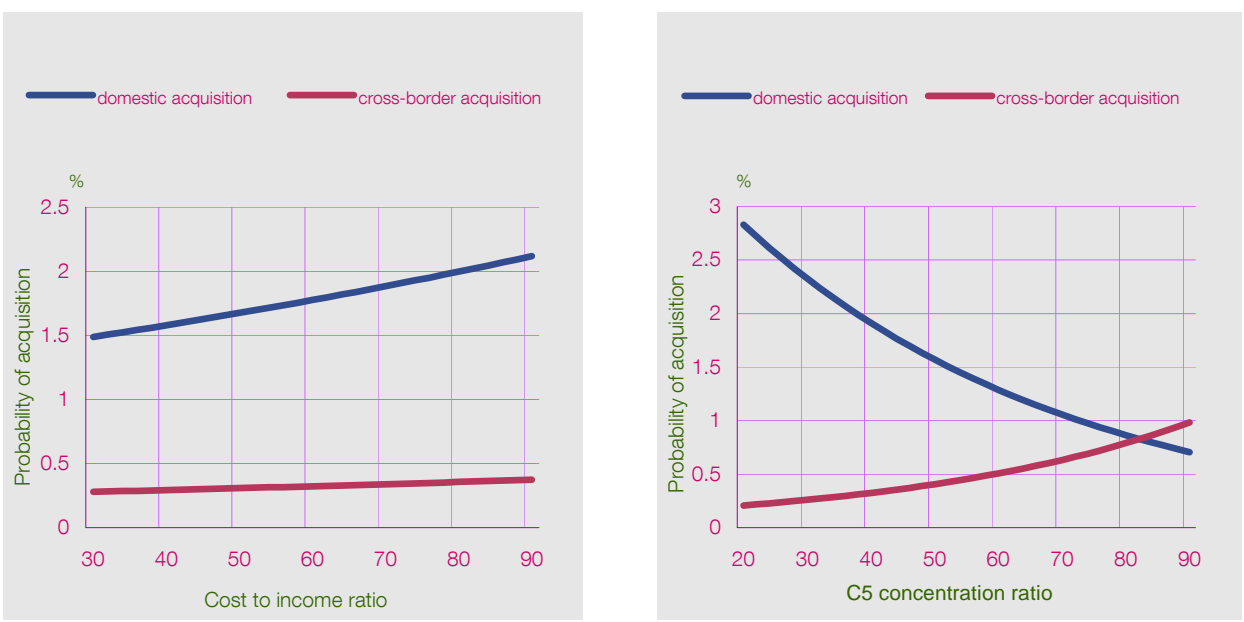

a. Probabilities computed for model [1] in table 6. A representative bank has been considered to be a commercial nonlisted one, located in a EU-15 country, with the continuous variables evaluated at their sample means. 
Table 1. Number of banks in the sample by country and year

Total number

Number acquired in a of banks

Home country of bank cross-border deal in the sample

Austria

Belgium

Cyprus

Czech Republic

Denmark

Estonia

Finland

France

Germany

Greece

Hungary

Ireland

Italy

Latvia

Lithuania

Luxembourg

Netherlands

Poland

Portugal

Slovakia

Slovenia

Spain

Sweden

United Kingdom

Total

-

-

the sample

Breakdown by year of announcement

\begin{tabular}{lcc}
1997 & 15 & 5 \\
1998 & 25 & 5 \\
1999 & 20 & 8 \\
2000 & 18 & 6 \\
2001 & 13 & 5 \\
2002 & 8 & 2 \\
2003 & 10 & 3 \\
2004 & 9 & 5 \\
\hline Total & 118 & 39
\end{tabular}

Sources: Thomson One Banker and Bureau van Dijk Bankscope 
Table 2. Summary statistics of banks that were acquired versus those of banks that were not acquired

\begin{tabular}{|c|c|c|c|c|c|}
\hline \multicolumn{2}{|c|}{$\begin{array}{c}\text { Sample of banks that } \\
\text { were acquired }^{\text {a }}\end{array}$} & \multicolumn{2}{|c|}{$\begin{array}{l}\text { Sample of banks that } \\
\text { were not acquired }\end{array}$} & \multirow{2}{*}{$\begin{array}{l}\text { Test on } \\
\text { Means }^{b} \\
\text { (p-value) }\end{array}$} & \multirow{2}{*}{$\begin{array}{l}\text { Test on } \\
\text { Medians }^{\mathrm{c}} \\
\text { (p-value) }\end{array}$} \\
\hline Mean & Median & Mean & Median & & \\
\hline
\end{tabular}

Ex-ante characteristics

Return on Average Assets (ROAA) \%

Return on Average Equity (ROAE) \%

Cost to Income Ratio \%

Net Int Rev / Avg Assets \%

Oth Op Inc / Avg Assets \%

Pre-Tax Op Inc / Avg Assets \%

Total Assets (thousand USD)

$0.18=0.38$

Deposits \& Short term funding (thousand USD)

$\begin{array}{rrrrrrl}0.18 & 0.38 & 0.68 & 0.50 & 0.09{ }^{*} & 0.07^{\star} \\ 3.61 & 5.95 & 9.09 & 8.44 & 0.02{ }^{\star \star} & 0.01^{\star \star \star} \\ 79.42 & 74.25 & 67.41 & 64.87 & 0.00{ }^{\star \star \star} & 0.00^{\star \star \star} \\ 2.50 & 2.42 & 2.44 & 1.94 & 0.76 & 0.00^{\star \star \star} \\ 1.96 & 1.46 & 2.03 & 1.02 & 0.89 & 0.00^{\star \star *} \\ 0.17 & 0.63 & 0.76 & 0.70 & 0.14 & 0.56 \\ 21200.00 & 1644.80 & 21100.00 & 1163.74 & 0.99 & 0.16 \\ 17900.00 & 1460.58 & 15800.00 & 890.59 & 0.74 & 0.07^{\star} \\ 4473.28 & 568.00 & 4195.14 & 192.00 & 0.88 & 0.01^{\star \star *} \\ 117.10 & 9.94 & 139.21 & 6.23 & 0.73 & 0.24 \\ 9.59 & 7.26 & 10.43 & 6.31 & 0.50 & 0.16 \\ 14.80 & 11.15 & 16.58 & 12.30 & 0.45 & 0.03^{\star \star}\end{array}$

${ }^{\star \star *} / \star^{* \star} /{ }^{*}$ denote significance at the $10 \% / 5 \% / 1 \%$ level.

a Statistics for the sample of banks that were acquired correspond to the year before the acquisition.

${ }^{b}$ The difference of means tests are generated from regressions that pool the data from the two groups of banks being compared. These regressions are specified as: $X_{i t}=a+b^{*} D_{i t}+e_{i t}$, where $X_{i t}$ is the variable being tested, $D_{i t}$ is a dummy equal to 1 for banks that were acquired.

${ }^{c}$ The difference of median tests are non-parametric two-sample tests for the null hypothesis that the two samples of banks being compared were drawn from populations with the same median. 
Table 3: Banks that were acquired: financial ratios with respect to the median value of the market

\begin{tabular}{|c|c|c|c|c|c|c|c|c|c|c|c|}
\hline \multirow[b]{3}{*}{ Ex-ante characteristics ${ }^{a, b}$} & \multicolumn{3}{|c|}{ All target banks } & \multicolumn{5}{|c|}{ Listed target banks } & \multicolumn{3}{|c|}{ Non-listed target banks } \\
\hline & Mean & \multicolumn{2}{|c|}{ Median } & \multicolumn{2}{|c|}{ Mean } & \multicolumn{2}{|c|}{ Median } & \multicolumn{2}{|c|}{ Mean } & \multicolumn{2}{|c|}{ Median } \\
\hline & & & & & & & & & & & \\
\hline Return on Average Assets (ROAA) \% & -0.34 & * & -0.09 & $* * \star$ & -0.669 & & -0.04 & & -0.22 & * & $-0.14 *$ \\
\hline Return on Average Equity (ROAE) \% & -4.44 & $* \star *$ & -1.29 & * & -2.072 & & 0.60 & & -5.33 & 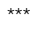 & -3.04 \\
\hline Cost to Income Ratio \% & 10.55 & $* * *$ & 6.90 & ** & 2.776 & & -0.25 & & 13.30 & *** & $7.94 *$ \\
\hline Net Int Rev / Avg Assets \% & -0.01 & & 0.00 & & 0.022 & & 0.15 & & -0.03 & & 0.00 \\
\hline Oth Op Inc / Avg Assets \% & 0.65 & $* * *$ & 0.06 & & 0.269 & & 0.05 & & 0.79 & *** & 0.08 \\
\hline Pre-Tax Op Inc / Avg Assets \% & -0.60 & * & -0.16 & * & -0.419 & & 0.06 & & -0.71 & $\star \star$ & -0.41 * \\
\hline Total Assets (USD millions) & 19500.00 & $\star * * *$ & 151.49 & & 31500.00 & ** & 1839.27 & $* * \star$ & 15100.00 & 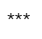 & -39.73 \\
\hline Deposits \& Short term funding (USD millions) & 16600.00 & $* * *$ & 759.28 & 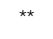 & 24700.00 & ** & 1519.31 & $* * *$ & 12100.00 & $* *$ & 89.44 \\
\hline Net Income (USD millions) & 108.27 & ** & 0.79 & & 123.98 & & 12.68 & 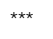 & 99.60 & * & -0.38 \\
\hline Number of Employees & 3967.25 & $* \star \star \star$ & 138.50 & * & 6440.120 & ** & 427.5 & 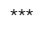 & 2730.82 & * & 22.50 \\
\hline Equity / Total Assets \% & 2.68 & $* * *$ & -0.01 & & 0.262 & & -0.57 & * & 3.57 & 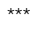 & 0.34 \\
\hline Total Capital Ratio \% & 2.91 & ** & -0.52 & ** & 0.398 & & -0.60 & & 4.53 & $\star \star \star$ & -0.45 \\
\hline
\end{tabular}


Table 4: Summary statistics of banks that were acquired: domestic versus cross-border deals

Ex-ante characteristics

Return on Average Assets (ROAA) \%

Return on Average Equity (ROAE) \%

Cost to Income Ratio \%

Net Int Rev / Avg Assets \%

Oth Op Inc / Avg Assets \%

Pre-Tax Op Inc / Avg Assets \%

Total Assets (USD millions)

Deposits \& Short term funding (USD millions)

Net Income (USD millions)

Number of Employees

Equity / Total Assets \%

Total Capital Ratio \%

$\begin{array}{ccccc}\begin{array}{c}\text { Sample of banks acquired } \\ \text { in domestic deals }\end{array} & \begin{array}{c}\text { Sample of banks acquired } \\ \text { in cross-border deals }\end{array} & \begin{array}{c}\text { Test on } \\ \text { Means }^{b}\end{array} & \begin{array}{c}\text { Test on } \\ \text { Medians }\end{array} \\ \text { Mean } & \text { Median } & \text { Mean } \quad \text { Median } & \text { (p-value) } & \text { (p-value) }\end{array}$

${ }^{* \star \star} /{ }^{* * / *}$ denote significance at the 10\%/5\%/1\% level.

a Statistics correspond to the year before the acquisition.

${ }^{b}$ The difference of means tests are generated from regressions that pool the data from the two groups of banks being compared. These regressions are specified as: $X_{i t}=a+b^{*} D_{i t}+e_{i t}$, where $X_{i t}$ is the variable being tested, $D_{i t}$ is a dummy equal to 1 for banks acquired in a cross-border deal.

c The difference of median tests are non-parametric two-sample tests for the null hypothesis that the two samples of banks being compared were drawn from populations with the same median. 
Variable

Cost to Income Ratio \%

Return on Average Equity (ROAE) \%

Net Interest Margin

Equity / Total Assets \%

Total Assets

Asset growth

Stock exchange listed

Five firm concentration ratio

$\mathrm{HHI}$

Country specific GDP growth

New Member States

Commercial bank binary

Medium and Long-term Credit binary

Holding Company binary

1999

2000

2001

2002

2003

2004

Intercept

Number of observations

Pseudo_R2

Log Likelihood

chi2

$\mathrm{AIC}$

***/**/* denote significance at the 10\%/5\%/1\% level.
[1]

[2]

$\begin{array}{cc}0.006^{\star \star \star} & 0.005^{\star \star \star} \\ -0.005 & -0.005 \\ 0 & -0.002 \\ 0.007 & 0.007 \\ 0.163^{\star \star \star} & 0.162^{\star \star \star} \\ -0.046 & -0.044 \\ 0.447^{\star} & 0.433^{\star} \\ -0.006 & \end{array}$

$-12.772^{\star \star}$

$1.314^{\star \star \star} \quad 1.353^{\star \star *}$

$0.927^{\star \star} \quad 0.902^{\star \star}$

$0.94 \quad 0.907$

$0.884 \quad 0.86$

$0.028 \quad 0.02$

$0.05 \quad 0.043$

$-0.56-0.589^{*}$

$-1.750^{\star \star *} \quad-1.782^{\star \star \star}$

$-0.842^{\star \star} \quad-0.874^{\star \star}$

$-0.840^{\star *} \quad-0.865^{\star \star}$

$-6.734^{\star \star *}-6.815^{\star \star \star}$

$5493 \quad 5493$

$0.055 \quad 0.055$

$-479.679 \quad-479.939$

$55.933 \quad 55.412$

$999.357 \quad 999.878$ 
Table 6 Multinomial logit results for the likelihood of being acquired by a domestic or a foreign bank: Reported values for bank specific variables

Variable

\section{Domestic deal}

Cost to Income Ratio \%

Return on Average Equity (ROAE) \%

$\begin{array}{cc}0.006^{\star \star \star} & 0.006^{\star \star \star} \\ -0.006 & -0.006 \\ 0.04 & 0.035 \\ 0.005 & 0.005 \\ 0.201^{\star \star \star} & 0.198^{\star \star \star} \\ -0.086 & -0.075 \\ 0.346 & 0.315 \\ -0.020^{\star \star \star} & \\ & -0.001^{\star \star} \\ -14.125^{\star \star} & -16.695^{\star \star} \\ 1.884^{\star \star \star} & 2.084^{\star \star \star} \\ 1.045^{\star \star} & 0.983^{\star \star} \\ 1.043 & 0.981 \\ 1.034 & 1.004 \\ -0.211 & -0.231 \\ -0.063 & -0.075 \\ -0.798^{\star} & -0.905^{\star \star} \\ -1.788^{\star \star \star} & -1.913^{\star \star \star} \\ -0.939^{\star \star} & -1.061^{\star \star} \\ -1.108^{\star \star} & -1.207^{\star \star \star} \\ -7.137^{\star \star \star} & -7.327^{\star \star \star} \\ & \end{array}$

Equity / Total Assets \%

Total Assets

Asset growth

Stock exchange listed

Five firm concentration ratio

$\mathrm{HHI}$

Country specific GDP growth

New Member States

Commercial bank binary

Medium and Long-term Credit binary

Holding Company binary

1999

2000

2001

2002

2003

2004

Intercept

$-7.137^{\star \star \star}$

0.005

s-border deal

Cost to Income Ratio \%

0.005

$-0.003$

Return on Average Equity (ROAE) \%

$-0.003$

Equity / Total Assets \%

$-0.204$

0.009

Total Assets

0.01

0.048

Asset growth

0.043

0.029

Stock exchange listed

$0.774^{*}$

$0.792^{*}$

Five firm concentration ratio

$0.022^{\star \star}$

$\mathrm{HHI}$

Country specific GDP growth

New Member States

Commercial bank binary

Medium and Long-term Credit binary

$-7.644$

$0.001^{* *}$

$-0.287$

$-6.307$

0.674

$-0.585$

Holding Company binary

1999

0.527

0.731

0.408

0.598

0.812

0.458

2000

0.528

0.842

0.576

0.363

2002

0.286

$-1.387$

2003

$-1.458$

$-0.285$

2004

Intercept

$-0.005$

0.026

$-7.577^{\star \star \star \star}$

$-7.290^{\star \star \star}$

\section{Statistics}

Number of observations

Pseudo_R2

Log Likelihood

0.068

0.066

chi2

$-528.932$

$-530.321$

$\mathrm{AlO}$

77.316

74.537

${ }_{\star \star \star \star}^{* \star \star} /{ }^{*}$ denote significance at the 10\%/5\%/1\% level.

1137.864

1140.643 
Table 7 Multinomial logit results of the likelihood of being acquired by a domestic or a foreign bank: Bank specific variables relative to mean of national market $\left(^{*}\right)$

Variable

\section{Domestic deal}

Relative Cost to Income Ratio \%

$0.005^{\star}$

$0.005^{\star}$

Relative ROAE \%

$-0.006$

$-0.006$

Relative Net Interest Margin

$-0.027$

$-0.027$

Relative Equity / Total Assets \%

0.003

0.003

Total Assets

Asset growth

Stock exchange listed

Five firm concentration ratio

$0.168^{\star * *}$

$0.167^{\text {*** }}$

$-0.081$

$-0.071$

$\mathrm{HHI}$

0.412

Country specific GDP growth

New Member States

Commercial bank binary

Medium and Long-term Credit binary

$-0.021^{\star \star \star}$

Holding Company binary

1999

2000

2001

2002

2003

2004

Intercept

$-14.852^{* *}$

$1.939^{\star \star \star}$

$1.122^{\star \star}$

1.075

$1.147^{\star}$

0.373

$-0.211$

$-0.045$

$-0.825^{\star \star}$

$-1.769^{\star \star \star}$

$-0.935^{\star \star}$

$-1.090^{* *}$

$-0.001^{\star *}$

$-17.569^{\star \star \star}$

$2.162^{\star \star \star}$

$1.060^{\star \star}$

1.019

$1.117^{\star}$

$-0.233$

$-0.058$

$-0.937^{\star *}$

$-1.905^{\star \star \star}$

$-1.065^{\star *}$

$-6.205^{\star \star \star}$

$-1.197^{\star \star *}$

\section{Cross-border deal}

Relative Cost to Income Ratio \%

Relative ROAE \%

Relative Net Interest Margin

Relative Equity / Total Assets \%

Total Assets

Asset growth

Stock exchange listed

Five firm concentration ratio

$\mathrm{HHI}$

Country specific GDP growth

$-0.001$

$0.006^{*}$

$-0.169$

$-0.001$

0.013

0.078

0.025

$-0.175$

0.012

0.076

0.606

$0.020^{\star \star}$

New Member States

Commercial bank binary

Medium and Long-term Credit binary

$-5.821$

$-0.457$

0.659

0.659

0.022

0.643

Holding Company binary

1999

0.44

0.818

$0.001^{* *}$

$-4.599$

$-0.732$

0.712

0.702

0.48

0.845

0.546

0.595

2000

0.317

0.391

2002

$-1.415$

$-1.342$

$-0.229$

$-0.17$

0.081

0.111

2004

$-8.133^{\star * *}$

$-7.751^{\star \star *}$

Statistics

Number of observations

$$
5493
$$

5493

0.065

$-530.739$

0.063

Log Likelihood

73.703

$-531.851$

chi2

1141.477

71.478

1143.702

${ }^{*}$ ) The variables Relative Cost to Income Ratio \%, Relative ROAE \%, Relative Net Interest Margin, and Relative Equity / Total Assets \% are defined as the individual bank ratio minus the median ratio of banks operating in that country.

${ }_{\star \star * * / * \star} /{ }^{*}$ denote significance at the 10\%/5\%/1\% level. 


\section{BANCO DE ESPAÑA PUBLICATIONS}

\section{WORKING PAPERS ${ }^{1}$}

0701 PRAVEEN KUJAL AND JUAN RUIZ: Cost effectiveness of R\&D and strategic trade policy.

0702 MARÍA J. NIETO AND LARRY D. WALL: Preconditions for a successful implementation of supervisors' prompt corrective action: Is there a case for a banking standard in the EU?

0703 PHILIP VERMEULEN, DANIEL DIAS, MAARTEN DOSSCHE, ERWAN GAUTIER, IGNACIO HERNANDO, ROBERTO SABBATINI AND HARALD STAHL: Price setting in the euro area: Some stylised facts from individual producer price data.

0704 ROBERTO BLANCO AND FERNANDO RESTOY: Have real interest rates really fallen that much in Spain?

0705 OLYMPIA BOVER AND JUAN F. JIMENO: House prices and employment reallocation: International evidence.

0706 ENRIQUE ALBEROLA AND JOSÉ M. ${ }^{a}$ SERENA: Global financial integration, monetary policy and reserve accumulation. Assessing the limits in emerging economies.

0707 ÁNGEL LEÓN, JAVIER MENCÍA AND ENRIQUE SENTANA: Parametric properties of semi-nonparametric distributions, with applications to option valuation.

0708 ENRIQUE ALBEROLA AND DANIEL NAVIA: Equilibrium exchange rates in the new EU members: external imbalances vs. real convergence.

0709 GABRIEL JIMÉNEZ AND JAVIER MENCÍA: Modelling the distribution of credit losses with observable and latent factors.

0710 JAVIER ANDRÉS, RAFAEL DOMÉNECH AND ANTONIO FATÁS: The stabilizing role of government size.

0711 ALFREDO MARTÍN-OLIVER, VICENTE SALAS-FUMÁS AND JESÚS SAURINA: Measurement of capital stock and input services of Spanish banks.

0712 JESÚS SAURINA AND CARLOS TRUCHARTE: An assessment of Basel II procyclicality in mortgage portfolios.

0713 JOSÉ MANUEL CAMPA AND IGNACIO HERNANDO: The reaction by industry insiders to M\&As in the European financial industry.

0714 MARIO IZQUIERDO, JUAN F. JIMENO AND JUAN A. ROJAS: On the aggregate effects of immigration in Spain.

0715 FABIO CANOVA AND LUCA SALA: Back to square one: identification issues in DSGE models.

0716 FERNANDO NIETO: The determinants of household credit in Spain.

0717 EVA ORTEGA, PABLO BURRIEL, JOSÉ LUIS FERNÁNDEZ, EVA FERRAZ AND SAMUEL HURTADO: Update of the quarterly model of the Bank of Spain. (The Spanish original of this publication has the same number.)

0718 JAVIER ANDRÉS AND FERNANDO RESTOY: Macroeconomic modelling in EMU: how relevant is the change in regime?

0719 FABIO CANOVA, DAVID LÓPEZ-SALIDO AND CLAUDIO MICHELACCI: The labor market effects of technology shocks.

0720 JUAN M. RUIZ AND JOSEP M. VILARRUBIA: The wise use of dummies in gravity models: Export potentials in the Euromed region.

0721 CLAUDIA CANALS, XAVIER GABAIX, JOSEP M. VILARRUBIA AND DAVID WEINSTEIN: Trade patterns, trade balances and idiosyncratic shocks.

0722 MARTÍN VALLCORBA AND JAVIER DELGADO: Determinantes de la morosidad bancaria en una economía dolarizada. El caso uruguayo.

0723 ANTÓN NÁKOV AND ANDREA PESCATORI: Inflation-output gap trade-off with a dominant oil supplier.

0724 JUAN AYUSO, JUAN F. JIMENO AND ERNESTO VILLANUEVA: The effects of the introduction of tax incentives on retirement savings.

0725 DONATO MASCIANDARO, MARÍA J. NIETO AND HENRIEITE PRAST: Financial governance of banking supervision.

0726 LUIS GUTIÉRREZ DE ROZAS: Testing for competition in the Spanish banking industry: The Panzar-Rosse approach revisited.

0727 LUCÍA CUADRO SÁEZ, MARCEL FRATZSCHER AND CHRISTIAN THIMANN: The transmission of emerging market shocks to global equity markets.

0728 AGUSTÍN MARAVALL AND ANA DEL RÍO: Temporal aggregation, systematic sampling, and the Hodrick-Prescott filter.

0729 LUIS J. ÁLVAREZ: What do micro price data tell us on the validity of the New Keynesian Phillips Curve?

0730 ALFREDO MARTÍN-OLIVER AND VICENTE SALAS-FUMÁS: How do intangible assets create economic value? An application to banks.

1. Previously published Working Papers are listed in the Banco de España publications catalogue. 
0731 REBECA JIMÉNEZ-RODRÍGUEZ: The industrial impact of oil price shocks: Evidence from the industries of six OECD countries.

0732 PILAR CUADRADO, AITOR LACUESTA, JOSÉ MARÍA MARTíNEZ AND EDUARDO PÉREZ: El futuro de la tasa de actividad española: un enfoque generacional.

0733 PALOMA ACEVEDO, ENRIQUE ALBEROLA AND CARMEN BROTO: Local debt expansion... vulnerability reduction? An assessment for six crises-prone countries.

0734 PEDRO ALBARRÁN, RAQUEL CARRASCO AND MAITE MARTíNEZ-GRANADO: Inequality for wage earners and self-employed: Evidence from panel data.

0735 ANTÓN NÁKOV AND ANDREA PESCATORI: Oil and the Great Moderation.

0736 MICHIEL VAN LEUVENSTEIJN, JACOB A. BIKKER, ADRIAN VAN RIXTEL AND CHRISTOFFER KOK-SØRENSEN: A new approach to measuring competition in the loan markets of the euro area.

0737 MARIO GARCÍA-FERREIRA AND ERNESTO VILLANUEVA: Employment risk and household formation: Evidence from differences in firing costs.

0738 LAURA HOSPIDO: Modelling heterogeneity and dynamics in the volatility of individual wages.

0739 PALOMA LÓPEZ-GARCÍA, SERGIO PUENTE AND ÁNGEL LUIS GÓMEZ: Firm productivity dynamics in Spain.

0740 ALFREDO MARTÍN-OLIVER AND VICENTE SALAS-FUMÁS: The output and profit contribution of information technology and advertising investments in banks.

0741 ÓSCAR ARCE: Price determinacy under non-Ricardian fiscal strategies.

0801 ENRIQUE BENITO: Size, growth and bank dynamics.

0802 RICARDO GIMENO AND JOSÉ MANUEL MARQUÉS: Uncertainty and the price of risk in a nominal convergence process.

0803 ISABEL ARGIMÓN AND PABLO HERNÁNDEZ DE COS: Los determinantes de los saldos presupuestarios de las Comunidades Autónomas.

0804 OLYMPIA BOVER: Wealth inequality and household structure: US vs. Spain.

0805 JAVIER ANDRÉS, J. DAVID LÓPEZ-SALIDO AND EDWARD NELSON: Money and the natural rate of interest: structural estimates for the United States and the euro area.

0806 CARLOS THOMAS: Search frictions, real rigidities and inflation dynamics.

0807 MAXIMO CAMACHO AND GABRIEL PEREZ-QUIROS: Introducing the EURO-STING: Short Term INdicator of Euro Area Growth.

0808 RUBÉN SEGURA-CAYUELA AND JOSEP M. VILARRUBIA: The effect of foreign service on trade volumes and trade partners.

0809 AITOR ERCE: A structural model of sovereign debt issuance: assessing the role of financial factors.

0810 ALICIA GARCÍA-HERRERO AND JUAN M. RUIZ: Do trade and financial linkages foster business cycle synchronization in a small economy?

0811 RUBÉN SEGURA-CAYUELA AND JOSEP M. VILARRUBIA: Uncertainty and entry into export markets.

0812 CARMEN BROTO AND ESTHER RUIZ: Testing for conditional heteroscedasticity in the components of inflation.

0813 JUAN J. DOLADO, MARCEL JANSEN AND JUAN F. JIMENO: On the job search in a model with heterogeneous jobs and workers.

0814 SAMUEL BENTOLILA, JUAN J. DOLADO AND JUAN F. JIMENO: Does immigration affect the Phillips curve? Some evidence for Spain.

0815 ÓSCAR J. ARCE AND J. DAVID LÓPEZ-SALIDO: Housing bubbles.

0816 GABRIEL JIMÉNEZ, VICENTE SALAS-FUMÁS AND JESÚS SAURINA: Organizational distance and use of collateral for business loans.

0817 CARMEN BROTO, JAVIER DÍAZ-CASSOU AND AITOR ERCE-DOMÍNGUEZ: Measuring and explaining the volatility of capital flows towards emerging countries.

0818 CARLOS THOMAS AND FRANCESCO ZANETTI: Labor market reform and price stability: an application to the Euro Area.

0819 DAVID G. MAYES, MARÍA J. NIETO AND LARRY D. WALL: Multiple safety net regulators and agency problems in the EU: Is Prompt Corrective Action partly the solution?

0820 CARMEN MARTÍNEZ-CARRASCAL AND ANNALISA FERRANDO: The impact of financial position on investment: an analysis for non-financial corporations in the euro area.

0821 GABRIEL JIMÉNEZ, JOSÉ A. LÓPEZ AND JESÚS SAURINA: Empirical analysis of corporate credit lines.

0822 RAMÓN MARÍA-DOLORES: Exchange rate pass-through in new Member States and candidate countries of the EU.

0823 IGNACIO HERNANDO, MARÍA J. NIETO AND LARRY D. WALL: Determinants of domestic and cross-border bank acquisitions in the European Union.

\begin{tabular}{|r|c|}
\hline & Unidad de Publicaciones \\
BANCODEESPANA & Alcalá, 522; 28027 Madrid \\
Eurosistema & Telephone +34 91 338 6363. Fax +34 913386488 \\
& e-mail: publicaciones@bde.es \\
www.bde.es
\end{tabular}

